\title{
ANALISIS STRUKTUR JARINGAN KOMUNIKASI DALAM ADAPTASI EKONOMI, SOSIAL DAN BUDAYA PADA PAGUYUBAN BABUL AKHIRAT DI KOTA BATAM
}

\author{
Ageng Rara Cindoswari \\ Program Studi Ilmu Komunikasi, Universitas Putera Batam \\ email: cindoswari@gmail.com
}

\begin{abstract}
The purposes of this study include: (1) To know the communication network on the Babul Akhirat community in the economic, social, and cultural adaptation; (2) To identify individual roles in the communication network of the Babul Akhirat community in the economic, social, and cultural adaptation; and (3) To describe the communication network centrality of the Babul Akhirat community in the economic, social, and cultural adaptation. This study constitutes a descriptive research with the quantitative approach. The study design of communication network is a complete network and the focus of this study was at the system level. In this study, the researcher referred to the nominalist approach by viewing the study population. The actor determination in this study was based on the positional strategy, namely the Babul Akhirat Community in Batam City where the actors becoming samples of the population were members of the Babul Akhirat community. Sampling used in this study was the samples of small groups, that were all members of the Babul Akhirat community, amounted to 82 members. This study used the analysis technique of sociometric data and the communication network structures by using by using UCINET VI. The results of this study showed: (1) The social and economic communication network took possession of the interlocking network structure; (2) The individual roles in the communication network of the Babul Akhirat community in the economic, social, and cultural adaptation encompassed opinion leader, cosmopolite, and bridge; and (3) The actors representing the highest local centrality value for the communication network of economic adaptation were node 15, 22, 30 , and 59, while values of the communication network for the social adaptation were node 22 and 31 , and values of the network communication for the cultural adaptation were node 30,47, and 45. On the other result, actors representing the lowest global centrality value for each communication network of economic adaptation, social adaptation, and cultural adaptation were node 23, node 5, and node 13.
\end{abstract}

Keywords: Communication Network Structure, Actor, Babul Akhirat Community

\section{PENDAHULUAN}

Kota Batam memiliki daya tarik yang tinggi bagi para pencari pekerjaan untuk datang. Perkembangan ekonomi yang pesat berdampak pada hadirnya migran yang berdatangan untuk mencari pekerjaan. Terdapat beberapa etnis pendatang yang memiliki jumlah cukup banyak di Kota Batam seperti Padang, Batak, Jawa, Sunda, Bali dan Flores.
Bercampurnya berbagai etnis di Kota Batam setidaknya terjadi persaingan sumber daya yang berujung pada sentimen-sentimen etnis dan berujung pada konflik etnis. Kondisi ini dapat dihindari oleh etnis pendatang yang memiliki perbedaan nilai dan budaya sehingga diperlukan berbagai strategi penyesuaian diri (adaptasi) dengan masyarakat setempat yang juga memiliki nilai yang berbeda. 
Keberadaan etnis pendatang memiliki karakteristik tersendiri dalam interaksi dengan sesamannya dan juga dengan etnis lain. Sebagai kaum pendatang mereka memiliki berbagai strategi untuk bisa melangsungkan hidupnya, memenuhi berbagai kebutuhannya dan juga mencapai apa yang menjadi tujuan mereka merantau dari wilayah asal mereka. Selanjutnya, dalam praktek keseharian mereka di hadapkan oleh berbagai pilihan strategi dalam pemenuhan kehidupan mereka, sebagian besar dari mereka membentuk kelompok sosial sebagai wadah komunikasi, aspirasi, fasilitasi serta pengembangan jaringan sosial terkait dengan pemenuhan kebutuhan informasi ekonomi, sosial dan budaya.

Berdasarkan penelitian yang dilaku-kan oleh peneliti sebelumnya mengenai jaringan komunikasi dan perilaku pencarian informasi dengan adaptasi etnis pendatang di Kota Batam ditemukan salah satu bentuk strategi adaptasi etnis pendatang adalah dengan membentuk dan bergabung ke dalam sebuah kelompok sosial keetnisan yang disebut dengan paguyuban. Melalui keterlibatan dalam sebuah paguyuban pendatang mengharapkan adanya wadah komunikasi dimana didalamnya terjadi pertukaran informasi yang dapat memenuhi kebutuhan informasi dalam rangka adaptasi di daerah perantauan. Paguyuban merupakan bentuk kehidupan bersama di mana dasar hubungan tersebut adalah rasa cinta dan rasa kesatuan batin yang memang telah dikodratkan. Bentuk paguyuban terutama akan dijumpai di dalam keluarga, kelompok kekerabatan, rukun tetangga dan lain sebagainya.

Pemenuhan kebutuhan yang dilakukan etnis pendatang di daerah rantau memerlukan suplai informasi yang beragam dan berasal dari sumber yang kredibel. Beberapa diantara mereka membentuk jaringan komunikasi sebagai sarana dalam berkomunikasi dan ber- interaksi dengan sesama maupun dengan etnisetnis lain. Jaringan komunikasi menyediakan berbagai informasi terkait dengan pemenuhan kebutuhan adaptasi mereka terkait dengan informasi mengenai ekonomi, sosial dan budaya. Oleh karena itu penting untuk melakukan analisa jaringan komunikasi memberikan gambaran mekanisme dan proses produksireproduksi informasi etnis pendatang sebagai pola interaksi mereka.

Pada penelitian sebelumnya ditemukan adanya hubungan antara jaringan komunikasi dengan perilaku adaptasi etnis pendatang sunda di paguyuban babul akhirat. Selanjutnya ditemukan munculnya berbagai tokoh star yang menjadi opinion leader pada jaringan komunikasi tersebut. Kemudian menjadi pertanyaan lanjutan adalah apakah tokoh star ini berbeda pada struktur jaringan komunikasi yang berbeda untuk setiap isu atau jenis informasinya?apakah latar belakang atau background star ini yang mengakibatkan mereka muncul sebagai star? Apakah pada setiap struktur jaringan komunikasi hanya muncul satu peran opinion leader saja? Bagaimana setiap struktur jaringan komunikasi memiliki kemampuan daya jangkau yang berbeda pada setiap struktur?

Beberapa pertanyaan lanjutan diatas dapat ditemukan dalam penelitian ini. Pada penelitian ini analisis struktur jaringan komunikasi memberikan pemetaan mengenai konstruksi aliran informasi yang teridentifikasi dari percakapan antar anggota paguyuban mengenai informasi yang diperlukan dalam rangka beradaptasi secara eknomi, sosial dan budaya. Hal ini penting untuk dilakukan karena analisis struktur mampu menyajikan data relational yang tidak didapatkan pada jenis penelitian survey kuantitatiflainnya. Data mengenai relational dalam studi komunikasi untuk menjelaskan beberapa fenomena diba- 
lik data yang disajikan melalui penelitian lainnya. Melalui data relational dapat didapat penjelasaan mengenai karakteristik, motif, pola individu berkomunikasi sehingga di akhir analisanya mampu merumuskan aktoraktor mana saja yang dapat didekati untuk menggiring perilaku anggota sistem untuk tujuan-tujuan koletif tertentu.

Anggota paguyuban babul akhirat yang merupakan etnis Sunda pendatang memilih strategiberadaptasi dengan bergabungke dalam sebuah kelompok sosial berupa pagguyuban. Melalui paguyuban ini mereka mendapatkan, menerima dan menyebarluaskan informasi yang dapat memenuhi kebutuhan beradaptasi di daerah perantauan. Berdasarkan arus pertukaran informasi sehingga terbentuklah jaringan komunikasi yang membentuk struktur tertentu untuk kegunaan beradaptasi. Adaptasi secara ekonomi, sosial dan budaya dalam penelitian ini ditelusuri berdasarkan pertukaran informasi terkait dengan informasi ekonomi, sosial dan budaya. Informasi meliputi adaptasi ekonomi terkait dengan informasi mengenai lapangan pekerjaan, modal kerja dan jaringan atau relasi kerja. Informasi mengenai adaptasi sosial terkait dengan informasi kesehatan dan pendidikan serta informasi mengenai adaptasi budaya terkait dengan informasi kekerabatan seperti pada pernikahan dan kelahiran.

Berdasarkan latar belakang di atas, rumusan permasalahan dalam penelitian ini meliputi (1). Apa struktur jaringan komunikasi paguyuban babul akhirat dalam adaptasi ekonomi, sosial dan budaya. (2). Apa saja peran-peran individu di dalam jaringan komunikasi paguyuban babul akhirat dalam adaptasi ekonomi, sosial dan budaya, (3). Bagaimana sentralitas jaringan komunikasi paguyuban babul akhirat dalam adaptasi ekonomi, sosial dan budaya.

\section{Pengertian, Konsep, dan Analisis Jaringan Komunikasi}

Jaringan komunikasi menurut Rogers and Kincaid (1981) adalah suatu jaringan yang terdiri atas individu-individu yang saling berhubungan, yang dihubungkan oleh arus komunikasi yang terpola. Begitu pula Hanneman and McEver yang dikutip oleh Djamali (1999) menyatakan bahwa jaringan komunikasi adalah pertukaran informasi yang terjadi secara teratur antara dua orang atau lebih. Jaringan komunikasi adalah aspek struktural dari sebuah kelompok, jaringan tersebut menjelaskan kepada kita bagaimana kelompok tetap bersatu atau terikat satu sama lain (Leavitt, 1992).

Rogers and Kincaid (1981) membedakan struktur jaringan komunikasi kedalam jaringan personal jari-jari (Radial Person Network) dan jaringan personal saling mengunci (Interlocking Personal Network). Jaringan personal yang memusat (interlocking) mempunyai derajat integrasi yang tinggi. Jaringan personal yang menyebar (radial) mempunyai derajat integrasi yang rendah, namun mempunyai sifat keterbukaan terhadap lingkungannya. Rogers dan Kincaid menegaskan, individu yang terlibat dalam jaringan komunikasi interlocking terdiri dari individu-individu yang homopili, namun kurang terbuka terhadap lingkungannya.

Jaringan personal radial memiliki kepadatan yang sedikit dan lebih terbuka terhadap pertukaran informasi pada lingkungan dan memungkinkan individu fokal untuk bertukar informasi dengan lingkungan yang lebih luas. Jaringan radial berisikan orangorang yang memiliki kenalan berjarak jauh (ikatan lemah) yang berguna sebagai saluran untuk memperoleh informasi. Ikatan yang lemah memiliki banyak bridge yang menghubungkan dua atau lebih klik. Ikatan 
yg lemah memiliki peran yang sangat penting karena mengantarkan informasi-informasi baru. Jaringan personal radial sangat penting dalam difusi inovasi karena link-link yang ada mencapai seluruh sistem, sementara jaringan mengunci (interlocking) lebih tumbuh ke arah dalam secara alamiah. Sistem yang tumbuh ke arah dalam merupakan jaringan yang sangat miskin untuk menangkap informasi baru dari suatu lingkungan (Rogers, 2003).

Analisis jaringan komunikasi dengan menggunakan sosiogram juga dapat memperlihatkan peran-peran individu dalam berinteraksi dengan sesamanya melalui jaringan komunikasi. Terdapat beberapa istilah yang digunakan dalam menggambarkan peranperan individu yang terlibat dalam jaringan komunikasi yaitu:(1). Opinion leader, (2). Gate keepers, (3). Cosmopolite, (4). Bridge, (5). Liaison, (6). Isolate.Scott (2000) menyatakan indikator terhadap jaringan dapat dilihat dari beberapa derajat pengukuran yakni (a). Koneksi (connectedness), (b). Keterjangkauan (reachability), (c). Resiprositas (reciprocity), (d). Kepadatan (density), (e). Sentralitas (centrality), (f). Kebersamaan (betweeness). Sentralitas merupakan pengukuran terhadap jaringan komunikasi yang ditemukan dalam konsep sosiometric sebagai "star" yakni orang yang "populer" dalam kelompoknya atau yang berdiri di pusat perhatian. Individu yang menjadi "star" berlokasi pada pusat jika memiliki sejumlah hubungan yang besar dengan individu lainnya dalam lingkungan yang dekat. Derajat pengukuran sentralitas terdiri dari derajat beragam individu dalam sosiogram yang dapat menunjukkan seberapa baik terhubungnya individu tertentu dengan lingkungan lokal mereka, sehingga sentralitas juga dapat digunakan untuk mengukur keterungulan seseorang dalam sistem.

Sentralitas dibagi menjadi dua, sentralitas lokal (local centrality) dan sentralitas global (global centrality). Sentralitas lokal adalah derajat dimana seorang individu berhubungan dengan individu lain dalam sistem. Sentralitas lokal menunjukkan jumlah hubungan yang dapat dibuat individu dengan individu lain dalam sistem. Menurut Freeman (1979) yang dikutip oleh Scott (2000), sentralitas lokal dapat bersifat relatif. Hal ini akan menjadi sangat penting jika ukuran kelompok tidak sama. Local centrality atau sentralitas lokal memperhatikan keunggulan relatif dari individu fokus dalam hubungan pertetanggaan.

Freeman (1979) yang dikutip oleh Scott (2000) telah mengusulkan pengukuran sentralitas global berdasarkan pada istilah seputar "closeness" atau kedekatan dari individu. Pengukuran sentralitas global Freeman diekspresikan dalam istilah "distance" diantara beragam individu. Global centrality atau sentralitas global memperhatikan keunggulan individu dengan keseluruhan jaringan. Nilai sentralitas global menunjukkan jumlah ikatan yang seseorang butuhkan untuk menghubungi semua individu dalam jaringan. Semakin kecil nilai sentralitas global menujukkan semakin mudah bagi seseorang untuk menghubungi semua individu dalam jaringan.

\section{Adaptasi Ekonomi, Sosial dan Budaya Anggota Paguyuban Babul Akhirat}

Adaptasi adalah kemampuan atau kecenderungan makhluk hidup dalam menyesuaikan diri dengan lingkungan baru untuk dapat tetap hidup dengan baik (Simanjuntak, 1992). Adaptasi dapat dilihat sebagai usaha untuk memelihara kondisi kehidupan dalam menghadapi perubahan. Definisi adaptasi tersebut kemudian ber-kaitan erat dengan tingkat pengukuran yang dihubungkan dengan tingkat keber-hasilannya agar dapat bertahan hidup. 
Adaptasi yang terjadi pada setiap suku bangsa ada beberapa tipe model, diantaranya adalah (1) adaptasi yang dilakukan pendatang terhadap penduduk setempat; (2) adaptasi yang dilakukan penduduk setempat oleh pendatang dan; (3) adaptasi yang tidak dilakukan oleh pihak manapun, di mana masing-masing suku bangsa saling berdiam diri tanpa melakukan adaptasi (Sianturi, 1999). Di tinjau dari sisi migran, paling tidak ada tiga fokus dalam beradaptasi di lingkungan baru. Fokus pertama adalah masalah keberlangsungan dalam menghadapi berbagai tantangan serta mendapatkan kesempatan pekerjaan di daerah tujuan. Fokus kedua, corak dan proses penyesuaian diri dalam lingkungan sosial yang serba baru. Fokus ketiga, kemungkinan kelanjutan atau keterputusan hubungan sosio- kultural dan ekonomi dengan daerah asal dan kemungkinan bertahan atau terleburnya identitas kultural lama ke dalam ikatan baru.

Ketiga fokus adaptasi diatas tidak terlepas dari adanya interaksi yang merupakan syarat utama proses sosial dimana adaptasi merupakan salah satu fenomena proses sosial. Menurut Gillin dan Gillin (1954) dikutip Soekanto (2012) Interaksi sosial merupakan hubungan-hubungan sosial yang dinamis yang menyangkut hubungan antara orang-perorang, antara kelompok-kelompok manusia, maupun antara orang perorang dengan kelompok manusia. Interaksi sosial antara kelompokkelompok manusia terjadi antara kelompok tersebut sebagai kesatuan dan biasanya tidak menyangkut pribadi anggota-anggotanya. Suatu interaksi memerlukan syarat dalam prakteknya yaitu (1). Adanya kontak sosial dan (2). Adanya komunikasi. Kontak berasal dari bahasa Latin con atau cum (yang artinya bersama-sama) dan tango (yang artinya menyentuh) sehingga secara harfiah artinya bersama-sama menyentuh (Soekanto, 2012).
Anggota paguyuban babul akhirat yang merupakan etnis Sunda pendatang memilih strategiberadaptasi dengan bergabung ke dalam sebuah kelompok sosial berupa pagguyuban. Melalui paguyuban ini mereka mendapatkan, menerima dan menyebarluaskan informasi yang dapat memenuhi kebutuhan beradaptasi di daerah perantauan. Berdasarkan arus pertukaran informasi sehingga terbentuklah jaringan komunikasi yang membentuk struktur tertentu untuk kegunaan beradaptasi. Adaptasi secara ekonomi, sosial dan budaya dalam penelitian ini ditelusuri berdasarkan pertukaran informasi terkait dengan informasi ekonomi, sosial dan budaya. Informasi meliputi adaptasi ekonomi terkait dengan informasi mengenai lapangan pekerjaan, modal kerja dan jaringan atau relasi kerja. Informasi mengenai adaptasi sosial terkait dengan informasi kesehatan dan pendidikan serta informasi mengenai adaptasi budaya terkait dengan informasi kekerabatan seperti pada pernikahan dan kelahiran.

Penelitian ini menggunakan para-digma kuantitatif yang bersifat deskriptif. Penelitian jaringan komunikasi dengan tipe deskriptif adalah penelitian yang dimaksudkan untuk menggambarkan secara detail struktur dan aktor-aktor dalam jaringan (Eriyanto, 2014). Jaringan utuh dalam penelitian ini adalah jaringan komunikasi etnis sunda pendatang dalam pencarian informasi ekonomi dalam rangka melakukan adaptasi di daerah perantauan. Pada analisis jaringan utuh, semua aktor (node) dalam jaringan ikut dianalisis sehingga tidak memusatkan pada satu actor saja (ego). Fokus penelitian ini yakni pada level sistem, dimana jaringan yang terbentuk dalam penelitian ini berasal dari populasi sasaran penelitian. Penelitian ini tidak lagi melihat aktor atau kelompok tetapi lebih kepada struktur jarigan secara keseluruhan. (Eriyanto, 2014). 
Penelitian ini dilakukan pada anggota paguyuban babul akhirat yang merupakan perantau beretnis Sunda di Kota Batam. Penelitian ini dilakuka selama 8 bulan sejak bulan Juli 2015 sampai bulan Januari 2016. Lokasi penelitian dipilih secara purposive (sengaja) dengan mempertimbangkan bahwa komplek tersebut merupakan pusat kegiatan aktivitas paguyuban etnis Sunda di Kota Batam. Fokus penelitian pertukaran informasi terkait adaptasi ekonomi, sosial dan budaya yang membentuk sebuah jaringan komunikasi di kalangan perantau anggota paguyuban babul akhirat. Informasi adaptasi ekonomi diantaranya adalah lapangan pekerjaan, modal kerja dan jaringan kerja. Informasi adaptasi sosial diantaranya adalah pendidikan dan kesehatan. Informasi budaya diantaranya adalah kekerabatan dalam pernikahan, kelahiran dan kematian.

Pada penelitian ini peneliti mengacu pada pendekatan nominalis dalam memandang populasi penelitian. Merujuk pada Lauman (1983) dalam Eriyanto (2014) pendekatan nominalis melihat bahwa jaringan dan definisinya bisa ditentukan berdasarkan kerangka konseptual dari peneliti. Peneliti dapat mendefinisikan jaringan dan batasbatasnya sesuai dengan tujuan dan kerangka penelitian yang dipakai. Peneliti membuat batasan aktor dan jaringan yang akan diteliti dengan merujuk pada teori tertentu atau pertimbangan tertentu. Penentuan aktor pada penelitian ini dilakukan berdasarkan strategi positional, dimana penentuan aktor atau anggota populasi didasarkan pada keanggotaan (posisi) seseorang dalam batasan tertentu seperti wilayah, perusahaan, organisasi dan sebagainya (knoke and Yang, 2008; Marsden, 2005; Scoot, 2000; Carolan 2013 dalam Eriyanto 2014). Berdasarkan pemilihan populasi dan strategi penentuan anggota populasi (aktor) yang dipilih oleh peneliti, maka populasi dari penelitian ini adalah paguyuban babul akhirat dimana yang bertindak menjadi anggota populasi (aktor) adalah anggota paguyuban babul akhirat.

Penarikan sampel yang digunakan dalam penelitian ini yakni sampel kelompok kecil. Peneliti mengambil satu kelompok dan mengambil semua anggota dari kelompok tersebut. Peneliti kemudian menggambarkan secara lengkap jaringan yang terbentuk dari kelompok tersebut (Wasserman and Faust, 1994; Scoot, 2000 dalam Eriyanto 2014) berdasarkan metode penarikan sampel yang dipilih dalam penelitian ini sehingga dapat dikatakan bahwa sampel penelitian ini adalah seluruh anggota paguyuban babul akhirat yang berjumlah 82 orang.

Penelitian ini menggunakan beberapa indikator pengukuran sentralitas yang ada pada studi jaringan komunikasi. berikut adalah indikator penelitian yang digunakan yakni :

1. Sentralitas lokal adalah derajat yang menunjukkan seberapa baik terhubungnya individu tertentu dalam lingkungan terdekat atau pertetanggaan mereka. Derajat ini menunjukkan jumlah hubungan maksimal yang mampu dibuat individu tertentu dengan individu lain yang berada dalam lingkungan terdekatnya dengan menggunakan UCINET VI, derajat sentralitas lokal diperoleh melalui "normalized degree centrality" atau "centrality degree". Nilai sentralitas lokal diperoleh melalui network $>$ centrality $>$ degree.

2. Sentralitas global adalah derajat yang menunjukkan berapa jarak yang harus dilalui oleh individu tertentu untuk menghubungi semua individu di dalam sistem. Derajat ini menunjukkan kemampuan individu untuk dapat menghubungi 
semua individu da-lam sistem, dengan menggunakan software UCINET VI, nilai sentralitas global diperoleh melalui "centrality closeness". Nilai sentralitas global diperoleh melalui network $>$ centrality> closeness.

Data yang dikumpulkan berupa data primer. Data primer diperoleh melalui wawancara kepada responden menggunakan kuisioner untuk menggali data kuantitatif. Pengumpulan data mengenai keterlibatan responden dalam jaringan komunikasi dilakukan dengan mengajukan pertanyaan sosiometri, yaitu pertanyaan dari siapa seseorang mendapatkan informasi tertentu dan kepada siapa seseorang membicarakan informasi tertentu. Melalui jawaban atas pertanyaan sosiometri yang telah ada dapat dibentuk sosiogram untuk melihat pola komunikasi, arus pertukaran informasi serta peran-peran individu yang terlibat dalam jaringan komunikasi (Rogers and Kincaid 1981).

Data penelitian dikumpulkan, dikategorisasikan, dianalisis dan disajikan secara deskriptif dalam bentuk rataan, persentase, dan tabel distribusi frekuensi. Data yang dikumpulkan diolah dan dianalisis berdasarkan kepentingan penelitian. Dalam penelitian ini teknik analisis data yang digunakan adalah (1). Analisis sosiometri untuk mendeskripsikan jaringan komunikasi paguyuban babul akhirat terkait dengan informasi ekonomi, sosial dan budaya (2). Analisis struktur jaringan komunikasi untuk melihat derajat sentralitas lokal, sentralitas global serta analisa struktur lainnya yang menggunakan software UCINET VI.

\section{PEMBAHASAN}

Struktur Jaringan Komunikasi Paguyuban Babul Akhirat Dalam Adaptasi Ekonomi, Sosial Dan Budaya.
Sosiogram yang menggambarkan struktur jaringan komunikasi diantara anggota paguyuban mengenai adaptasi ekonomi dapat dilihat pada Gambar 1. Struktur jaringan komunikasi mengenai adaptasi ekonomi cenderunglebihterbukadengan lingkungannya. Hal ini terlihat dari masih terdapat celah pada klik-klik tertentu yang memungkinkan adanya pertukaran informasi sesama partisipan yang berkomunikasi. Struktur komunikasi diantara sesama partisipan yang berkomunikasi seperti ini disebut oleh Rogers and Kinkaid (1981) sebagai jaringan personal yang menyebar (radial personal network). Jaringan personal yang menyebar (radial personal network) mempunyai derajat integrasi yang rendah, namun mempunyai sifat keterbukaan terhadap lingkungannya.

Struktur jaringan yang memiliki celahcelah terbuka antar klik dalam pertukaran informasi terkait adaptasi ekonomi menandakan tingkat pertukaran informasi yang tinggi yang terjadi pada setiap klik. Kondisi seperti ini yang memungkinkan jaringan komunikasi berkembang sehingga ukuran jaringan juga akan semakin besar. Pada struktur seperti ini memungkinkan adanya pergantian ataupun bermunculan aktoraktor baru pada peran-peran dalam jaringan. Struktur seperti ini menihilkan keberadaan peran isolate. Kondisi ini disebabkan iklim jaringan yang padat informasi sehingga tidak memungkinkan adanya individu yang tidak berkomunikasi sama sekali. Kemudian, hal ini juga dikarenakan adaptasi ekonomi merupakan hal pokok yang perlu dilakukan perantau, sehingga menutup kemungkinan adanya individu yang tidak berusaha mencari dan mendapatkan informasi ekonomi.

Sosiogram yang menggambarkan struktur jaringan komunikasi diantara anggota paguyuban megenai adaptasi sosial dapat 
dilihat pada Gambar 2. Struktur jaringan komunikasi mengenai adaptasi sosial sama halnya dengan jaringan komunikasi adaptasi ekonomi juga cenderung lebih terbuka dengan lingkungannya. Hal ini terlihat dari masih terdapat celah pada klikklik tertentu yang memungkinkan adanya pertukaran informasi sesama partisipan yang berkomunikasi. Struktur komunikasi diantara sesama partisipan yang berkomunikasi seperti ini disebut oleh Rogers and Kinkaid (1981) sebagai jaringan personal yang menyebar (radial personal network).

Jaringan personal radial memiliki kepadatan yang sedikit dan lebih terbuka terhadap pertukaran informasi pada lingkungan dan memungkinkan individu fokal untuk bertukar informasi dengan lingkungan yang lebih luas. Jaringan radial berisikan orang-orang yang memiliki kenalan berjarak jauh (ikatan lemah) yang berguna sebagai saluran untuk memperoleh informasi. Ikatan yang lemah memiliki banyak bridge yang menghubungkan dua atau lebih klik. Ikatan yg lemah memiliki peran yang sangat penting karena mengantarkan informasi-informasi baru (Rogers, 2003).

Jaringan komunikasi etnis sunda anggota paguyuban babul akhirat mengenai budaya digambarkan dalam sosiogram pada Gambar 3 . Pada gambar tersebut terlihat struktur jaringan komunikasi mereka merupakan struktur jaringan personal memusat (interlocking personal network). Menurut Rogers dan Kincaid (1981) jaringan personal yang memusat (interlocking) mempunyai derajat integrasi yang tinggi. Selanjutnya Rogers dan Kincaid menegaskan, individu yang terlibat dalam jaringan komunikasi interlocking terdiri dari individuindividu yang homopili, namun kurang terbuka terhadap lingkungannya. Kondisi ini terlihat pada sosiogram di Gambar 3, dimana terjadi pemusatan arus informasi pada satu individu yang memiliki hubungan total maksimal pada semua individu yang menjadi anggota di dalam sistem. Pemusatan juga terjadi di setiap klik dimana, individu anggota klik cenderung berkomunikasi pada satu individu.

Struktur jaringan komunikasi seperti ini mengakibatkan arus informasi yang saling dipertukarkan antar partisipan tidak sepadat struktur jaringan komunikasi radial. Terdapat sedikit individu yang berperan sebagai bridge yang menjembatani antar klik. Hal ini disebabkan oleh karakteristik informasi yang yang dipertukarkan terkait dengan pemeliharaan dan sosialisasi budaya perantau di wilayah rantauan. Kecenderungan perantau untuk mempertukarkan informasi cenderung hanya pada orang-orang se-etnis dan hanya pada orang-orang yang di"tua"kan, pemuka adat sehingga informasi cenderung sentralistik pada satu orang individu. Struktur jaringan seperti ini meminimalkan kemungkinan struktur jaringan komunikasi berubah dan berkembang karena komunikasi yang terjadi hanya pada individu homofili.

Menurut Rogers (2003) hakekat dari suatu jaringan komunikasi adalah hubunganhubungan yang bersifat homofili (homophilus), yakni kecenderungan manusia untuk melakukan hubungan atau kontak sosial dengan orangorang yang memiliki atribut sama atau yang lebih tinggi sedikit dari posisi dirinya. Tetapi dapat juga terjadi antar orang-orang yang memiliki atribut yang tidak sama. Setiap jenis jaringan komunikasi mempunyai kecepatan perkembangan yang berbeda-beda. Semakin penting suatu jenis informasi bagi suatu anggota sistem sosial, makin cepat perkembangan dan luas jangkauan jaringan komunikasinya. Jaringan komunikasi yang berhubungan dengan informasi tentang kebutuhan primer akan mempunyai jangkauan yang tercepat dan terjauh (Rogers, 2003). 


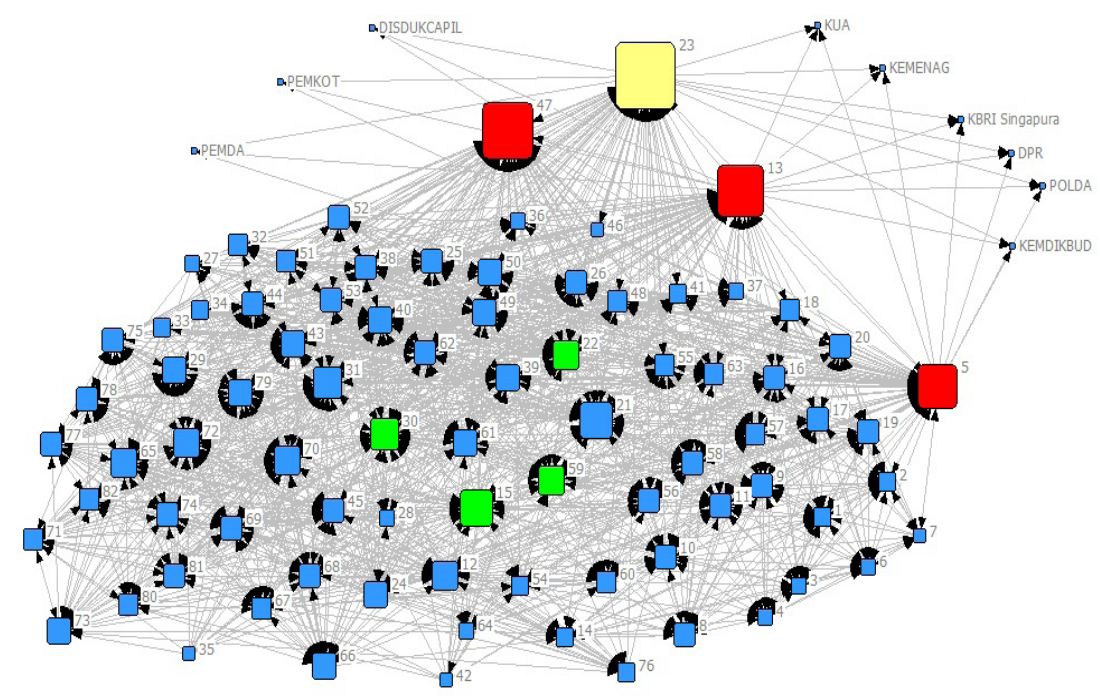

Gambar 1.

Struktur Jaringan Komunikasi Etnis Sunda Paguyuban Babul Akhirat dalam Adaptasi Ekonomi

Informasi yang kerap dipertukarkan dalam jaringan komunikasi budaya terkait informasihajatan kelahiran, hajatan pernikahan dan berita duka seperti kematian ataupun musibah lainnya. Bentuk jaringan komunikasi budaya berbeda dengan jaringan komunikasi lainnya yakni berstruktur mengunci (interlocking). Hal ini terlihat dari padatnya interaksi atau hubungan pada setiap individu maupun klik (lihat tanda garis pada Gambar 3). Posisi formal aktor cenderung menentukan posisi informal aktor dalam beberapa isu percakapan. Hal ini terjadi dikarenakan pada isu-isu budaya etnis sunda atau tradisi yang dijalankan pada upacara tertentu seperti pernikahan hanya diperbincangkan sesama etnis. Tidak semua etnis pendatang atau di luar suku sunda membicarakan tradisi tersebut dan memiliki kemampuan dalam mengakses informasi tersebut. Selain itu terlihat dalam analisa jaringan bahwa senioritas seperti faktor usia, senioritas dan ketokohan dalam penentuan posisi informal yang dijadikan sumber rujukan atau informasi dalam melakukan adaptasi budaya.

\section{Peran-Peran Individu Di Dalam Jaringan Komunikasi Paguyuban Babul Akhirat Dalam Adaptasi Ekonomi, Sosial Dan Budaya.}

Peran individu pada jaringan komunikasi paguyuban babul akhirat pada adaptasi ekonomi, sosial dan budaya adalah opinon leader, cosmopolite, dan bridge. Opinion leader adalah pimpinan informal dalam organisasi. Mereka ini tidaklah selalu orangorang yang mempunyai otoritas formal dalam organisasi tetapi membimbing tingkah laku anggota organisasi dan mempengaruhi keputusan mereka. Anggota paguyuban yang memiliki peran sebagai star dalam sosiogram jaringan komunikasi ditunjukkan oleh node yang memiliki derajat konektivitas tertinggi. Artinya, individu-individu tertentu yang paling banyak terhubung dengan individu lain merupakan individu yang dapat memainkan peran sebagai star. Sebagai individu yang terhubung dengan banyak individu yang lain menunjukkan tingkat popularitas yang dapat menjadikan dirinya sebagai star. Oleh karena itu, star kerap dijadikan 


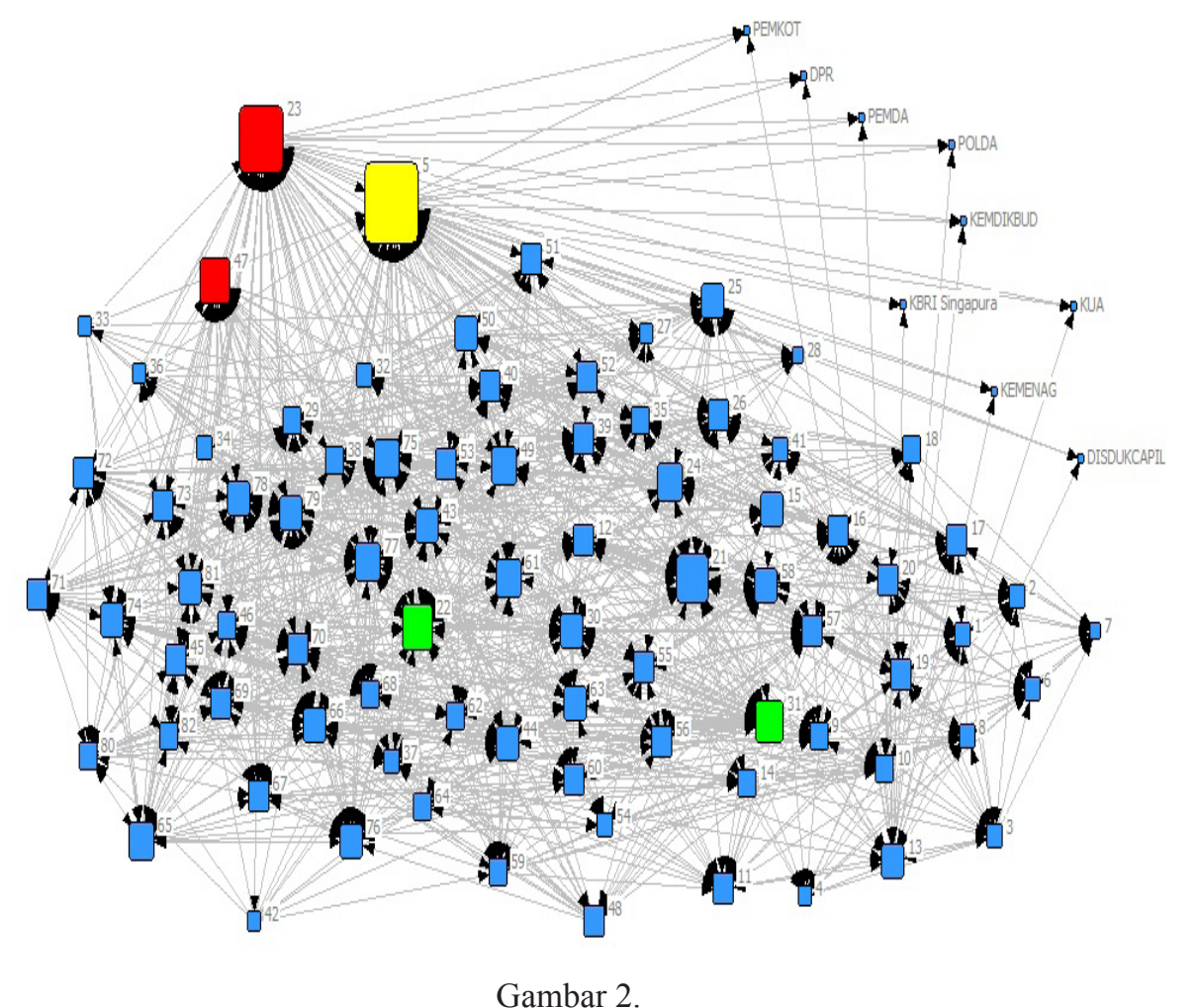

Struktur Jaringan Komunikasi Etnis Sunda Paguyuban Babul Akhirat dalam Adaptasi Sosial

sumber acuan atau sarana informasi oleh sesamanya dalam memutuskan sesuatu melalui tingkah laku yang ditunjukkan .

Sosiogram jaringan komunikasi adaptasi ekonomi di Gambar 1, menunjukkan terdapat star atau tokoh sentral untuk setiap klik. Peran sebagai star dalam klik pada jaringan komunikasi adaptasi ekonomi adalah node 47, 13 dan 5. Peran sebagai cosmopolite dalam sistem adalah node 23. Selanjutnya peran sebagai bridge adalah node 15, 21, 22, 30 dan 59. Node 47 adalah pak didi, node 13 adalah pak kodrat dan node 5 adalah pak deden. Pak didi merupakan anggota paguyuban yang dianggap sebagai salah satu tokoh Sunda di paguyuban babul akhirat yang ada di Kota Batam. Beliau adalah pensiunan DPRD Kepri dan berusia sekitar 60 tahun. Beliau merupakan sosok yang memiliki pergaulan luas baik di batam maupun di garut. Beberapa anggota paguyuban yang menjadi responden dalam penelitian ini mengaku termotivasi oleh pak didi untuk bermigrasi ke Batam. Selain memotivasi pak didi juga kerap menyediakan tempat tinggal bagi sanak saudara, kerabat, tetangga yang bermigrasi ke Batam. Informasi lapangan pekerjaan sering kali dating dari pak didi, inilah yang menjadikan beliau sebagai star dalam adaptasi ekonomi.

Node 13 adalah adalah pak kodrat yang merupakah tokoh ulama sekaligus tokoh etnis sunda yang paling dihormati dan dituakan. Pak kodrat berprofesi sebagai pendakwah yang juga salah satu pemilik yayasan prof. syamsudin. Pak kodrat berusia 68 tahun yang juga salah satu etnis sunda yang sangat pertama kali tinggal di Kota Batam. Sebagai tokoh masyarakat pak kodrat memiliki wawasan yang luas, pergaulan yang luas dan dikenal luas oleh masyarakat batam sebagai guru sekaligus pendakwah. Profesi dakwah yang digeluti oleh pak kodrat dijalankan sejak 
lama dan hal itu juga yang mendorong dirinya untuk melakukan hijrah ke batam agar dapat mengamalkan ilmu agama yang ia miliki. Sebagai tokoh masyrakat pak kodrat memiliki jaringan dan relasi yang luas di Kota Batam, ia bergaul dan berkomunikasi baik dari berbagai kalangan sehingga tidak heran jika paguyuban yang ia didirikan bersama dengan rekanrekan yang lain berkembang begitu pesat dan mendapat dukungan dari berbagai pihak termasuk dari pemerintah kota batam.

Node 5 adalah pak deden yang bertindak sebagai ketua pelaksana paguyuban babul akhirat. Pak deden berusia 42 tahun dan berprofesi sebagai kepala sekolah SMKAljabar milik dari yayasan Prof. Syamsudin. Sebagai tokoh etnis sunda muda yang juga memiliki jaringan komunikasi yang luas pak deden juga merupakan sosok yang aktif berorganisasi. Pak deden memiliki jaringan yang luas karena beliau juga merupakan seorang pendakwah yang berpengalaman berdakwah dibeberapa tempat baik di kota batam maupun di daerah di luar batam. Beberapa wilayah yang sering dikunjungi untuk berdakwah seperti kabupaten lingga, kabupaten karimun hingga sampai ke Negara Singapura dimana beliau memiliki relasi yang baik dengan KBRI di Singapura. Selain berprofesi sebagai pendakwah pak deden juga memiliki hubungan yang baik dengan sejumlah lembaga dan orang-orang penting yang dalam penelitian ini dianggap sebagai Node di luar sistem. Beberapa Node di luar sistem yang memiliki hubungan dengan pak deden diantaranya adalah POLDA, KUA, KEMENAG, KEMDIKBUD, DISDUKCAPIL, PEMKOT DAN KBRI SINGAPURA.

Cosmopolite adalah individu yang menghubungkan organisasi dengan lingkungannya. Mereka ini mengumpulkan informasi dari sumber-sumber yang ada dalam lingkungan dan memberikan informasi mengenai organisasi kepada orang-orang tertentu dalam

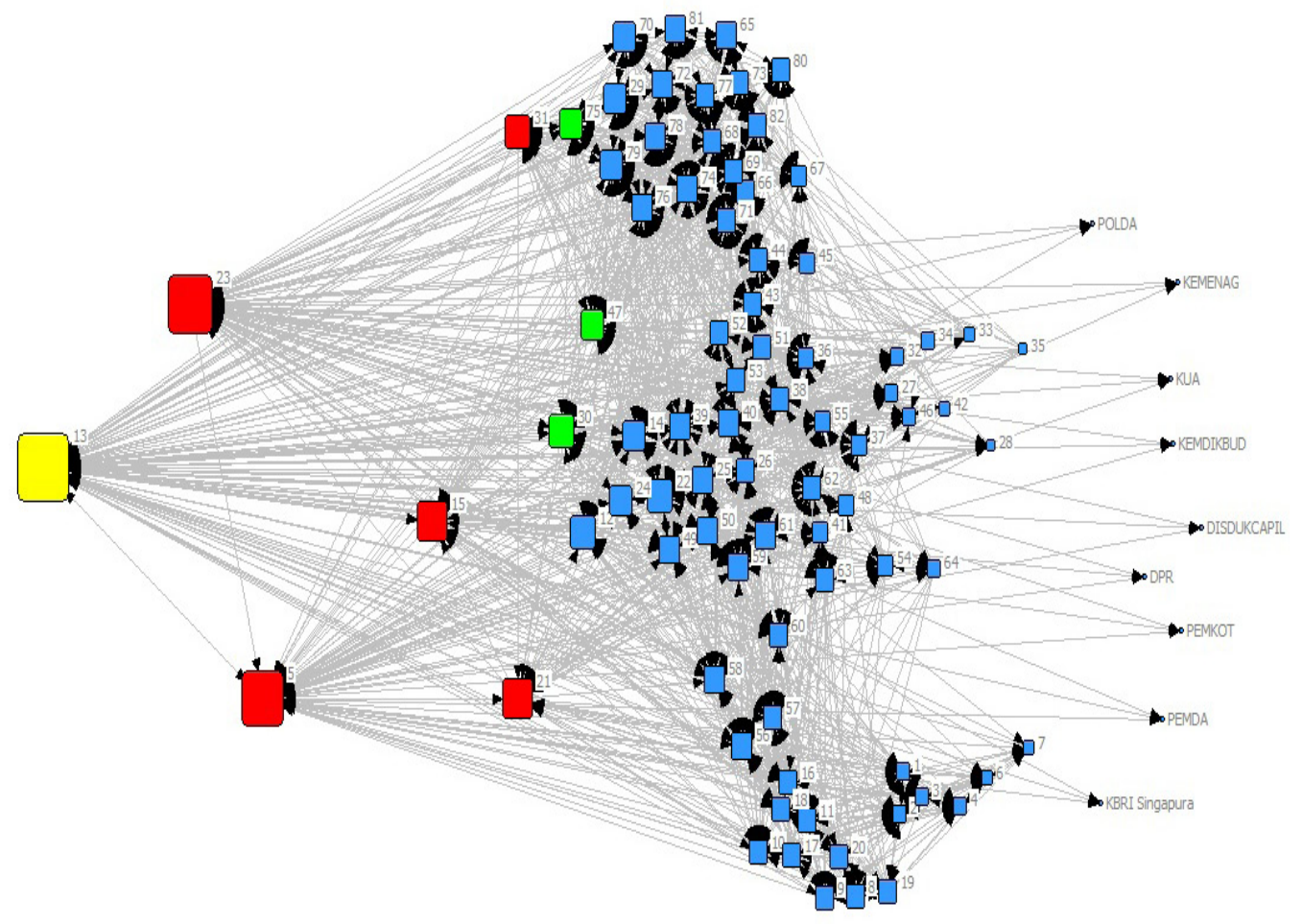

Gambar 3 .

Struktur Jaringan Komunikasi Etnis Sunda Paguyuban Babul Akhirat dalam Adaptasi Budaya 
lingkungannya. Bridge adalah anggota kelompok atau klik dalam suatu organisasi yang menghubungkan kelompok itu dengan anggota kelompok lain. Individu ini membantu saling memberi informasi di antara kelompokkelompok dan mengkoordinasi kelompok.

Pada sosiogram jaringan komunikasi adaptasi sosial di Gambar 2, menunjukkan terdapat star atau tokoh sentral untuk setiap klik. Peran sebagai star dalam klik pada jaringan komunikasi adaptasi ekonomi adalah node 23 dan 47. Peran sebagai cosmopolite dalam sistem adalah node 5. Selanjutnya peran sebagai bridge adalah node 22 dan 31.Individu 23 dan 47 adalah pak yusron dan pak didi yang latar belakang atribut sosial telah dijelaskan pada bagian jaringan komunikasi ekonomi diatas. Sedangkan node 5 yang berperan sebagai cosmopolite adalah pak deden yang berperan sebagai tokoh utama dalam perbincangan mengenai informasi pendidikan dan kesehatan. Hal ini tidak terlepas dari latar belakang beliau sebagai kepala sekolah sebuah sekolah swasta yang kerap berhubungan dengan dinas pendidikan kota batam ataupun KEMDIKBUD sehingga mendapatkan informasi yang terkini dan terpercaya mengenai masalah pendidikan. Hal ini yang mengakibatkan beliau dapat berperan sebagai star sekaligus sebagai cosmopolite.

Individu yang berperan sebagai bridge adalah node 22 dan node 31 . Node 22 adalah pak agus dan node 31 adalah tatang. Pak agus dan pak tatang adalah anggota paguyuban yang memiliki konektivitas merata pada setiap klik yang berada dalam sebuah sistem. Posisi mereka yang berada ditengah inilah yang menjadikan mereka berfungsi sebagai perantara antar klik. Pak tatang merupakan anggota paguyuban yang memiliki kedekatan dengan beberapa pendiri dan tokoh star di setiap klik. Pak tatang bekerja sebagai pensiunan PNS dinas kesehatan Kota Batam yang berasal dari daerah yang sama dan bertetangga dengan Pak deden yakni daerah Sukabumi Jawa Barat. Sebagai tokoh yang aktif yang memiliki kedekatan dengan star lainnya pak tatang juga dikenal luas oleh anggota paguyuban dan juga masyarakat awam lainnya. Posisi ini memungkinkan beliau untuk dapat dijadikan sumber rujukan atau referensi terhadap adaptasi sosial.

Pada sosiogram jaringan komunikasi adaptasi budaya individu yang berperan sebagai star adalah node 5, 15, 21, 23, 31. Sedangkan yang berperan sebagai cosmopolite node 13 adalah selanjutnya yang berperan sebagai bridge adalah node 30, 47 dan 75 . Node 75 adalah ibu darojah atau sering disebut sebagai ibu syam (isteri prof.syamsudin). Individu ini berperan sebagai perantara antara klik-klik yang berada ke dalam sebuah sistem. Ibu darojah adalah pemilik yayasan Prof. Syamsudin dimana ia memiliki hubungan yang cukup dekat dengan beberapa penggagas dan pendiri paguyuban.

Ibu Darojah juga merupakan dewan Pembina sekolah menengah kejuruan Aljabar dan berusia 58 tahun. Ibu darojah termasuk etnis sunda yang cukup lama tinggal di kota batam mengikuti jejak suaminya prof. syamsudin yang hijrah ke batam pada tahun 1983. Sebagai seorang istri ulama (pendakwah) beliau memiliki jejaring komunikasi dan hubungan yang luas terkait dengan etnis sunda baik yang merupakan anggota paguyuban maupun bukan. Hubungan yang baik dan luas ini menjadikan ibu darojah dijadikan sebagai perantara antara klik-klik lain yang didominasi oleh laki-laki dengan klik-klik yang beranggotakan perempuan. Sikap ramah, terbuka dan dermawan juga merupakan faktor pendorong yang menjadikan ibu darojah sebagai perantara hal ini berakibat 
bagi mudahnya beliau berkomunikasi dengan berbagai star di dalam klik-klik di dalam sistem.

\section{Sentralitas Jaringan Komunikasi Paguyuban Babul Akhirat Dalam Adaptasi Ekonomi, Sosial Dan Budaya.}

Analisis jaringan komunikasi di tingkat individu dalam penelitian ini untuk melihat ukuran sentralitas lokal dan sentralitas global individu etnis sunda anggota paguyuban di Kota Batam. Menurut Scott (2000), Derajat pengukuran sentralitas terdiri dari derajat beragam individu dalam sosiogram yang dapat menunjukkan seberapa baik terhubungnya individu tertentu dengan lingkungan mereka. Sentralitas juga dapat digunakan untuk mengukur keterungulan seseorang dalam sistem. Nilai rata-rata, maksimum, minimum sentralitas lokal dan sentralitas global responden berdasarkan topik pembicaraan dalam jaringan komunikasi secara jelas dapat dilihat pada Tabel 1.

Tabel 1.

Nilai rata-rata, maksimum dan minimum sentralitas lokal dan sentralitas global anggota paguyuban mengenai adaptasi ekonomi, sosial dan budaya.

\begin{tabular}{|l|c|c|c|}
\hline $\begin{array}{c}\text { Jaringan } \\
\text { Komunikasi }\end{array}$ & Ekonomi & Sosial & Budaya \\
\hline Sentralitas Lokal \\
\hline Nilai Rata-rata & 17.00 & 14.00 & 17.00 \\
\hline Nilai Maksimum & 69.00 & 65.00 & 65.00 \\
\hline Nilai Minimum & 1.00 & 1.00 & 1.00 \\
\hline Sentralitas Global \\
\hline Nilai Rata-rata & 1.061 & 981 & 1.061 \\
\hline Nilai Maksimum & 8.190 & 1.055 & 8.190 \\
\hline Nilai Minimum & 912 & 916 & 916 \\
\hline
\end{tabular}

Sumber : Data Primer diolah dari UCINET, 2016

Berdasarkan Tabel 6 dapat dilihat bahwa nilai rata-rata sentralitas lokal anggota paguyuban untuk topik adaptasi ekonomi dan budaya menunjukkan angka 17.00 dan untuk topik adaptasi sosial menunjukkan angka 14.00 . Artinya, pada topik pembicaraan mengenai adaptasi ekonomi dan budaya anggota paguyuban rata-rata mampu menghubungi 14 individu mengenai lapangan pekerjaan, modal kerja dan jaringan kerja. Begitu pula dengan topik adaptasi budaya, dimana setiap individu anggota paguyuban rata-rata mampu menghubungi 17 individu untuk membicarakan mengenai informasi kelahiran, pernikahan dan kematian.

Nilai maksimum sentralitas lokal isu/ topik adaptasi ekonomi jaringan komunikasi menunjukkan 69 dan minimum 1. Nilai maksimum sentralitas lokal isu/topik adaptasi sosial dan budaya jaringan komunikasi menunjukkan 65 dan minimum 1. Artinya hal ini menunjukkan etnis sunda anggota paguyuban paling banyak dapat menghubungi 69 individu untuk isu adaptasi ekonomi seperti informasi mengenai lapangan pekerjaan, perolehan modal kerja dan perluasan jaringan kerja dan minimal dapat menghubungi 1 individu untuk berkomunikasi mengenai isu/ topik tersebut. Selanjutnya pada adaptasi mengenai sosial, anggota paguyuban minimal dapat menghubungi 1 individu dan maksimal 65 individu untuk membicarakan informasi mengenai pendidikan dan kesehatan. hal yang sama juga terdapat pada nilai sentralitas minimum dan maksimum pada isu/topik mengenai adaptasi budaya seperti informasi kelahiran, pernikahan dan kematian.

Berdasarkan tabel tersebut dapat disimpulkan bahwa setiap anggota paguyuban minimal dapat menghubungi 1 orang untuk membicarakan semua informasi terkait dengan aspek ekonomi, sosial dan budaya. Artinya tidak terdapat individu yang berperan sebagai isolate. Isolate adalah anggota organisasi yang mempunyai kontak minimal dengan orang lain dalam organisasi. Orang-orang 
ini menyembunyikan diri dalam organisasi atau diasingkan oleh teman-temannya. Hal ini dikarenakan oleh beberapa hal diantaranya adalah sikap terbuka yang dimiliki oleh anggota paguyuban dan status sebagai perantau yang mengharuskan mereka untuk melakukan adaptasi dengan berinteraksi satu sama lain agar dapat bertahan hidup di daerah perantauan baik dari aspek ekonomi, sosial maupun kebudayaan.

Berdasarkan analisis struktur jaringan komunikasi melalui sosiogram pada gambar 1 terlihat bahwa individu yang memiliki nilai sentralitas lokal tinggi adalah node 15, 22 dan 30. Node 15 adalah Gunawan, node 22 adalah agus, node 30 ilyas, node 59 adalah miftah. Selanjutnya pada sosiogram di gambar 2 individu yang memiliki sentralitas lokal tertinggi adalah node 22 dan 31 . Node 22 adalah Agus dan node 31 adalah tatang. Sosiogram pada gambar 3 menunjukkan individu yang memiliki nilai sentralitas lokal tertinggi adalan node 30, 47 dan 45 . Node 30 adalah ilyas, node 47 adalah didi, node 45 adalah maruli. Berdasarkan pemaparan sebelumnya beberapa individu yang memiliki nilai sentralitas local tinggi telah digambarka secara spesifik. Namun terdapat beberapa kesamaan hal yang dapat disimpulkan dari keseluruhan karakteristik individu yang memiliki sentralitas lokal tinggi. Pertama, memiliki latar belakang pendidikan yang cukup baik. Kedua, memiliki latarbelakang pekerjaan yang formal. Ketiga, memiliki keterdedahan terhadap lingkungan sosial dan arus informasi ekternal yang tinggi. Keempat, memiliki pengetahuan rohani yang cukup baik. Kelima, memiliki pengalaman tinggal di perantauan lebih lama daripada perantau lainnya yang tergabung di dalam paguyuban babul akhirat.

Pengukuran sentralitas global dieks- presikan dalam istilah "distance" diantara beragam individu. Global centrality atau sentralitas global memperhatikan keunggulan aktor dengan keseluruhan jaringan. Nilai sentralitas global menunjukkan jumlah ikatan yang seseorang butuhkan untuk meng-hubungi semua individu dalam jaringan. Sentralitas global dapat memberikan gam-baran kemampuan akses individu didalam sistem. Sentralitas global diperlukan sebagai bahan pertimbangan untuk memilih orang yang tepat sebagai kunci penyebar informasi. Semakin kecil nilai sentralitas global yang dimiliki individu maka semakin besar kemampuan individu tersebut untuk menghubungi semua orang dalam sistem (Scott, 2000).

Berdasarkan hasil analisis dengan menggunakan software UCINET VI pada Tabel 6, diperoleh nilai maksimum sentralitas global menunjukkan adaptasi ekonomi dan budaya 8.190 dan 1.055 untuk adaptasi sosial. Nilai minimum sentralitas global adaptasi ekonomi 912 dan nilai sentralitas global minimum adaptasi sosial dan budaya 916. Selanjutnya, nilai rata-rata sentralitas global adaptasi ekonomi dan adaptasi budaya adalah 1.061 dan nilai rata-rata sentralitas global adaptasi sosial adalah 981. Individu yang memiliki nilai sentralitas global terendah untuk topik jaringan komunikasi adaptasi ekonomi adalah node 23 yakni pak yusron, untuk adaptasi sosial adalah node 5 yakni pak deden dan untuk adaptasi budaya adalah node 13 yakni pak kodrat. Sentralitas global yang rendah menunjukkan sedikitnya distance yang harus ditempuh atau dilalui oleh seseorang untuk menghubungi semua individu lain dalam sebuahsistem. Dalam arti lain, seseorang yang hanya memerlukan distance yang pendek untuk menghubungi individu lainnya adalah seseorang yang memiliki kemampuan yang besar untuk dapat menjangkau semua individu 
dalam sistem jaringan komunikasinya. Oleh karena itu, orang tersebut dapat berperan sebagai kunci penyebar informasi. Melalui orang-orang inilah informasi-informasi baru dapat diterima dan disebarluaskan kepada seluruh anggota sistem.

Kunci penyebar informasi ini memiliki peranan yang kuat dalam suplai informasi ke dalamm jaringan. Mereka juga berperan sebagai penghubung antara sistem (baca: jaringan komunikasi ekonomi/sosial/ budaya) dengan iklim luar sistem. Keluasan daya jangkau (sempitnya distance) yang dimiliki oleh mereka memudahkan mereka menentukan dan mengelola informasi apa saja yang layak atau pantas untuk dipertukarkan dalam sistem. Pak yusron, pak kodrat dan pak deden merupakan orang-orang di dalam paguyuban babul akhirat yang memiliki latar belakang yang unik dan pribadi yang menarik sehingga menjadikan mereka mudah untuk bergaul dan baik di dalam sistem dan di luar sistem (baca:paguyuban). Disamping itu mereka memiliki profesi yang pengalaman pendidikan yang memungkinkan untuk banyak berhubungan dengan orang, sehingga tidak mengherankan mereka memiliki distance (jarak) yang pendek untuk dapat berhubungan dengan kunci penyebar informasi lainnya.

\section{PENUTUP}

\section{Simpulan}

1. Jaringan komunikasi ekonomi dan sosial memiliki struktur radial network sedangkan jaringan komunikasi budaya memiliki struktut interlocking network.

2. Peran individu pada jaringan komunikasi paguyuban babul akhirat pada adaptasi ekonomi, sosial dan budaya adalah opinon leader, cosmopolite, dan bridge.

3. Aktor yang memiliki nilai sentralitas lokal tertinggi untuk jaringan komuni-kasi adaptasi ekonomi adalah node 15, 22, 30, 59.Untuk jaringan komunikasi adaptasi sosial adalah node 22 dan 31. Untuk jaringan komunikasi adaptasi budaya adalah node 30,47 dan 75 . Aktor yang memiliki nilai sentralitas global terendah pada jaringan komunikasi adaptasi ekonomi adalah node 23, adaptasi sosial adalah node 5 dan adaptasi budaya adalah node 13 .

\section{Saran}

1. Struktur jaringan komunikasi mngenai adaptasi budaya diharapkan memilliki banyak bridge dan cosmopolite agar dapat perlahan-lahan merubah swtrukturnya menjadi radial network. Hal ini perlu dilakukan untuk memperkenalkan dan memelihara kebudayaan etnis Sunda di daerah rantauan. Dengan begitu toleransi dan rasa menghargai sesama etnis pendatang di Kota Batam dapat tercipta dan meminimalkan potensi konflik antar etnis yang berakibat buruk pada pembangunan Kota Batam.

2. Pengurus paguyuban dapat memberdayakan anggota paguyuban yang memiliki karakteristik tertentu seperti tingkat pendidikan, jenis pekerjaan, pergaulan sosial, pengetahuan agama dan lama menetap sebagai dasar pertimbangan untuk mempertahankan dan mengembangkan eksistensi paguyuban karena melalui orang-orang tersebut anggota paguyuban yang lain dapat digiring perilakunya untuk tujuan-tujuan koletif tertentu. 


\section{DAFTAR PUSTAKA}

Djamali RA. 1999. Analisis Jaringan Komunikasi dalam Bisnis Sarang Burung Walet di Kabupaten Jember Jawa Timur. Tesis. Bogor : Institut Pertanian Bogor.

Eriyanto. 2014. Jaringan Analisis Jaringan Komunikasi : Strategi Baru Dalam Penelitian Ilmu Komunikasi Dan Ilmu Sosial Lainnya. Jakarta : Kencana Prenada Media Group

Leavitt, Harold. 1992. Psikologi Manajemen. Diterjemahkan Oleh Muslichah Zarkasi. Jakarta : Erlangga.

Rogers, E.M and L. Kincaid. 1981.Communication Network: Toward A New Paradigm for Research. London: Collier Macmillan Publisher.

Scott. 2000. Social Network Analysis: AHand Book. Second Edition. California:SAGE Publications Inc.

Soekanto, Sarjono. 2012. Sosiologi Suatu Pengantar. Cetakan ke 44. Jakarta : Rajawali Press

Sianturi, E. Sostra M. 1999.Adaptasi Sosial Budaya Penduduk Asli Dan Pendatang Antara Masyarakat Pakpak Dairi Dengan Batak Toba. Skripsi Sarjana FISIPOL-USU.Tidak diterbitkan.

Simanjuntak, Walter P. 1992. Proses Adaptasi Sosial Budaya Orang Minangkabau Di Balige (Kajian Antropologis di Kelurahan Napitupulu Dan Kelurahan Lumban Dolok). Skripsi Sarjana. FISIPOL-USU. Tidak diterbitkan. Tubb, S.L dan Moss, S. 2009. Human Communication. Prinsip-Prinsip Dasar, Terjemahan. Bandung : Remaja Rosdakarya. 